\title{
DOWNTOWN IN SÃO PAULO WITH HILDEGARD ROSENTHAL'S CAMERA
}

David William Foster ${ }^{1}$

"Por diversas circunstâncias, o acervo de fotografias de Hildegard Rosenthal constitui-se num instrumento utilíssimo para pesquisadores preocupados em conhecer a forma com que a cidade de São Paulo era utilizada por seus protagonistas, os cidadãos comuns" (Toledo, "Um olhar" 13)

One of the best known images of Hildegard Rosenthal (1913-90), the Swiss-born photographer (but registered as a German national) who produced some three thousand images in São Paulo in the ten-year period from her arrival in Brazil in the late 1930s through the 1940s, is that of the camarão, the shrimp-colored tram that carried passengers in and out of the financial and commercial center of São Paulo. ${ }^{2}$ Tosta has examined the recurring image of the tram in the poetry of São Paulo--although he does not pick up the reference specifically to the camarão in the 1933 proletarian novel by Mara Lobo (pseud. of Patrícia Galvão), Parque industrial, notable because of its emphasis on the participation of women in the growing industrialization of the city in the boom years after the Great War. ${ }^{3}$ São

$1 \mathrm{PhD}$, Arizona State University - Languages and Literatures. Tempe, AZ 85287-0202 [david. foster@asu.edu]

2 This essay is part of a series of studies on São Paulo supported by a grant from the Jewish Studies Program of XXX State University.

3 Jackson's "Afterword" to the English translation remains the definitive critical study of this vrey unusual novel. 
Paulo began to undergo, in the 1920s, a process of enormous expansion that converted it from the modest seat of the coffee and other agricultural interests of the beginning of the century into the financial and industrial center, first of Brazil, and then of all Latin America. By the time of the much fabled Semana de Arte Moderna in early 1922, which provided the ab quo for an assertively national and cosmopolitan cultural production, ${ }^{4}$ and the arrival of foreign intellectuals who provided an impetus for the emerging sophistication of the city (the most famous was Claude Lévi-Strauss, who arrived in 1934 and who began in Brazil the work that went on to become so tremendously important for the development of contemporary anthropology), São Paulo had undergone many significant transformations. LéviStrauss's own photography of the city is to be found in Saudades de São Paulo; see also his Saudades do Brasil.

Certainly, the most representative was the emergence of a central urban core that anchored the growth of the city, with industrialization to the east, the concentration of immigrant masses to the north and east, and the construction of elegant residential satellites to the west and south. The development of the Universidade de São Paulo, which was crucial to the modernization of the city (and as part of which project Lévi-Strauss arrived in Brazil, although his relationship with the administration was not amiable and he did not long remain for any significant length of time on the faculty), was first developed out of facilities of the already existing Faculdade de Direito in the downtown area, moved in 1949 to a large and quite sumptuous site southwest of the urban center. The urban center of the city has historically been identified as the Praça da Sé, where the metropolitan cathedral is situated, although other points, such as the Praça da República, the Viaduto do Chá (one of the icons of the city), and the Avenida Paulista (site of branches of over fifty international banking houses) are equally predominant in the urban imaginary of São Paulo. It is in and out of this central core that the trams function, among them the colorful camarão that

4 Morse's history of São Paulo remains the definitive source on this spectacular growth; see also Font, who concentrates particularly on the economy of São Paulo. The third São Paulo that Toledo, São Paulo, examines in the one photographed by Rosenthal and Lévi-Strauss (the first and second, respectively, are the colonial city and the early, pre-1922, republican one). 
Rosenthal so notably photographed. Indeed, the tram or trolley car--and the motorized bus--appear in nine of the forty-six images gathered in the 1998 catalog of her photography, Cenas urbanas, published by São Paulo's Instituto Moreia Salles, which is now the repository of her monumental work.

But what is particularly noteworthy about this image is the way in which it captures the utilization of this vehicle of modern transportation to enhance its urban iconicity by having it serve as the billboard for a slogan of the São Paulo's urban growth. Long before such public forms of transportation were converted into dense texts of commercial and public service information, with advertisements and announcements plastered all over the exterior of the vehicle, its interior, and strategically at the stops and stations of its run, such that passengers can often read only a portion of these texts between one point and another of their itinerary, the São Paulo camarão displayed prominently the slogan of the city's self-consciousness regarding its important growth. The slogan reads "SÃO PAULO É O MAIOR CENTRO INDUSTRIAL DA AMÉRICA LATINA.” The capital letters of the text run almost the full length of the car, and they are, one might say, enclosed in the quotation marks of the front and rear doors through which pass the hundreds of passengers who read any one vehicle each day, all preponderantly involved in some financial or commercial way with supporting the assertion made by the slogan. The slogan appears as a banner in what appears to be a specially designed space whose height is exactly that of the capital letters and which occurs between the slight overhang of the curved exterior roof of the vehicle and a small overhang of the top of the vehicle that runs all the way around the vehicle above the front cab, the rows of windows, the two doors on the right side and the rear compartment.

This latter overhang constitutes a very emphatic underlining of the capitalized banner. Since the banner runs on the side of the bus where passengers mount and dismount the vehicle, they cannot help but contemplate an assertion the veracity of which their travel on the vehicle is likely contributing. This is a slogan that announces its text as much to the casual pedestrian of the city as it does to a large sector of the agents of the social 
text within which the slogan acquires its meaning. The indirect object of the implied predicate of assertion--"I say to YOU that. .."--is as much the casual observer who needs to be told this truth, as it is the individual who suspects it is true because of his or her daily toil within the industrial apparatus. ${ }^{5}$

Rosenthal's photograph is brilliant in the way in which it focuses the trolley. The vehicle is one of a line of trolleys parked at the major stop of the Praça de Correio (the imposing postoffice building may be seen in the upper right-hand background), and the body of the vehicle fills the central portion of the photo in a swath that reaches from border to border, although the focus is made more interesting by bleeding the rear of the vehicle outside the left-hand margin and my including a portion, bleeding out the right-hand border, a second vehicle, a positioning of the line of sight that underscores the way in which this vehicle is part of a supposedly large fleet of such cars, itself an index of the mass movement of the population as it goes about its business: to adapt Warren Harding famous phrase, "the business of São Paulo is business." ${ }^{6}$ The clean line of the trolley, which is accentuated by the horizontal banner of the slogan, itself parallel to the set of four safety bars that run the length of the windows, is repeated by a series of horizontally drawn spaces that run down the lower

5 The following passage from Galvão's Parque industrial confirms the nature of the bulk of the passengers who ride the trolleys: "O bonde se abarrota. De empregadinhas dos magazines. Telefonistas. Caixeirinhos. Toda a população de mais explorados, de menos explorados. Para os seus cortiços na imensa cidade proletária, o Brás" (26). Brás is one of the industrial neighborhoods to the east of the downtown area, the locale of the textile plants that appear in the novel and where Galvão, the black sheep of a comfortable bourgeois family, herself worked prior to writing the novel. See Warren Dean on the industrialization of the city.

6 Yet, the blithe pro-business spirit of São Paulo has not gone unchallenged, and Pochmann examines how the labor structure of the city actually creates un- and under-employment. This is a misery and poverty that is highlighted, for example, in recent Paulistano fiction and film, but hardly in Rosenthal's photography, which remains firmly entrenched in the boosterist image of the period. Abreu et al., however, not that the period of 1937-42, precisely the period of Rosenthal's photography, was one of economic stagnation (223). This makes her veritable boosterism all that much more impressive. Kossoy records Rosenthal's "rápida viagem pela propaganda [comercial]"--the impressive list of slogans, brand names, and commercial icons that appear in her photos (27). 
portion of the photography and bleed off outside the bottom margin. These spatial bands include the file of passengers waiting to board the vehicle (the single file is clearly discernible among the jumble of some fifty individuals (mostly men and all appropriately uniformed, in the best British fashion, for their occupation in the city $)^{7}$ moving around the open space recorded by the bottom half of the photograph), the strip of the passenger island, bordered itself by a curb, the bricked channel along which other vehicle might pass (clearly, this transit surface antedates the massive modern paving that universally characterizes the city today), and, finally, another pedestrian area, either an access sidewalk or another passenger island providing access to yet another set of vehicles (a larger image of the important set of bus stops in the Praça da Sé, along with parking areas for cars, may be studied in image no. 9 of Cenas urbanas). This sort of parallel geometry, so characteristic of the designs of modernism, certainly augments Rosenthal's representation of the bustling city. And note the appropriate use of verbs here: the premodern marketplace teams with individuals, but the modern commercial cityscape bustles with its denizens.

As an assertion, the slogan implies the need to establish São Paulo's ranking among the industrial cities of Latin America. Not only does it presuppose the possibility of employing the absolute adjective a maior, but it also presupposes an inventory of cities among which to establish São Paulo's ranking. This assumption is problematical at best, since one can well wonder what the level of any degree of industrialization is in Latin American in the late 1920s, early 1930s. Proletarian novels are scarce in Latin American literature in this period, which is that of the high point of a social realism denouncing the exploited factory worker of capitalism. Argentine literature involves a modest bibliography of narratives on

7 The casualness of public dress of the citizens of Rio de Janeiro has often been contrasted with the formality of dress of those of São Paulo, but the relaxation of dress codes in contemporary life and the blurring of distinctions between the two cities brought about by internal migration has led to less differentiation that was evident in the 1930s. This is also true with regard to the greater presence of people of color in Rio at that time and the very clear whitening effect of massive European migration experienced by São Paulo (pace the accompanying Japanese presence in the latter). 
vidas proletarias, a presence that will be addressed by the first Peronista government (1946-52), with its roots in the urban labor movement. ${ }^{8}$

However, in general in Latin America, a cultural production protesting the exploitation of the worker typically means the peon of agriculture or mining--that is, nonurban enterprises. This is equally true in Brazil, were texts by Rachel de Queiroz, Graciliano Ramos, José Lins do Rego all involve rural settings. ${ }^{9}$ This explains the importance of Galvão's Parque industrial, not only as a feminist text, but as a singular example of urban proletarian fiction. The simple fact is that, aside from industrialization in Argentine (meat packing enjoying a historical iconicity), it is questionable whether one can reasonably speak much of industrialization anywhere else in Latin America before projects of industrialization (along with economic theories of import substitution) such as those promoted by Perón in Argentina in the 1940s and Fidel Castro in Cuba in the 1960 s. ${ }^{10}$ Brazil has had such a long history of comprehensive industrialization that its neighbor, Argentina, has at times spoken of the bane of the dumping of Brazilian overproduction on the Argentine market.

As a consequence, the assertion that São Paulo is the major industrial center of Latin America cannot have been seen as occurring in the context of a contentious debate, except perhaps vis-à-vis Brazil's traditional Argentine rival (sometimes, it seems, in all things, from borders to soccer, from filmmaking to sin. . .), but certainly not in the face of any competition from its neighbors (Uruguay, Paraguay, Bolivia, among them) or from any other Latin American economy: in the 1920s, Mexico, for example, the other great economic power in Latin America along with Argentina and Brazil, was just beginning to recover from the horrors of the barbarous decade of the 1910 revolution, and prosperity only comes to that country after World War II in which, like Brazil, Mexico was a close ally of the United States and benefited accordingly. So to assert the primacy of São

8 Foster examines Argentine socialist realism/proletarian writing; I have found no similar study for Brazilian literature.

9 As do the texts of a social realist stamp by Spanish-language writers, like Peruvians César Vallejo and Ciro Alegría, the Colombian José Eustacio Rivera, the Guatemalan Miguel Ángel Asturias,

${ }^{10}$ See Abreu et al. on industrialization and import substitution in Brazil. 
Paulo's industrial primacy serves, perhaps, more to inspire the pride of the bustling bees of the industrial hive than to sort out economic realities. Perhaps, for Rosenthal, there was a certain measure of ironic glance to be associated with such an assertion, in the jejuneness of it all, especially for someone who had arrived in Brazil evading the horrors of the Nazism, founded as it was on in large measure on Germany's industrial capitalism.

Although Rosenthal was not herself Jewish, she left Germany during the early years of the Hitler regime because she had the temerity to marry a Jew (see biograhical notes De Franchesci). In Brazil, she was always accepted as something life an honorary Jew, and an important an intellectual and historian of photography as Boris Kossoy acknowledges her pertinence to the realm of Jewish cultural production in Brazil that he himself eminently represents (16). Certainly, Rosenthal is very much a part of Brazilian photography, appearing in standard reference works (e.g., Fernandez Junior), featured in prominent expositions, and accorded unique status by cultural foundations such as the Instituto Moreira Salles, which houses her negatives, on which it based a one-person show on whose exhibit catalog this essay is based; Rosenthal was also featured in a program by São Paulo's TV Unicsul/Canal Universitário do Sul, of the Universidade Cruzeiro do Sul. Although Rosenthal's work was essentially concentrated in the 1930s, her negatives run into the thousands, thereby providing a pretty much untapped documentary source for historians of this crucial period in Brazilian history, which corresponds with the tail-end of the halcyon years of cultural production that came out of the Semana de Arte Moderna, held in São Paulo in mid-February 1922, the period of the economic impact of the Great Depression, and the rise of Getúlio Vargas, who came to power by coup in 1930 and who imposed the fascistoid Estado Novo in 1937. While Rosenthal's photographs are not directly political in nature, they can be important to understand this period of intense social change in the country's major demographic, commercial, and financial center. ${ }^{11}$

${ }^{11}$ In general, Rosenthal's images capture the modern masculinist urb, and this is an important political reality in itself. However, one set of images involves the new Estádio Municipal, very much of a fascist area edifice, a fact that it confirmed by the geometric display of human bodies (i.e., the index of [the attempt to construct] a strictly regulated society) in some sort of public ceremony being held within its confines. 
Most commentators have underscored Rosenthal's primary interest in photography human being in public spaces. This is especially evident in the case of the photograph I have commented on at length above: rather than only framing the iconic camarão, as it might be found in a holding area after hours, she captures it in full function, surrounded by the bustling Paulistanos whose workday is facilitated by this colorful vehicle, with its upbeat gung-ho message regarding the preeminence of São Paulo's industrial base. There is a famous self-portrait of Rosenthal. Photographers are famous for their self-portraits, and this one is equally interested in the photographer as another human being, as another participant in the social commerce she is capturing: it is, therefore, intriguing to speculate as to the reasons when a photographer chooses not to include a self-portrait. ${ }^{12}$ Dating 1940 , this image shows a petite and very formally dressed woman. Her gaze is that of a worldly aristocrat, and one can imagine her roaming the downtown streets of São Paulo (not all of her images are from the central core of the city, but an impressive number are), lugging one of the almost unwieldy top-scale cameras of the day.

Rosenthal had an assistant, whom she was not above posing in her shots. Although none of her photos are stagy and she appeared not to have had an interest in photomontage, ${ }^{13}$ unlike her contemporary German

${ }^{12}$ Meskimmon examines self-portraits by women artists, including photography: "Self-portraiture is a way of coming into representation for women, in which the artist is both subject and object. . . She presents an embodied subject" (xv). The early twentieth century is certainly the period in which women are routinely becoming social subjects and representing themselves in their art, as in the case of Galvão's autobiographical or the self-portrait of a painter like Tarsila do Amaral.

${ }_{13}$ There is one photomontage included in Cenas urbanas, however. It is built on a photograph that provides a perspective of the bustling downtown area, with cars, pedestrians, trollies, and multistoried commercial buildings. To the right, looming up behind the five- or six-story buildings, but at an angle as though partially toppled by an earthquake, is a truly imposing late-nineteenth century building, of the sort about twenty stories in height, with multiple cornices to alleviate the uniformity of a single facade, all together quite rococo in appearance. To the right, striding as tall as latter building, with his spread feet planted over the comings and goings of the street far below his gaze, is a newspaper boy, hawking with both arms copies of the Jornal da manhã, one of the major forums of Paulistano commerce and finance. The perspective of this towering figure is foreshortened by the depiction of gathered clouds in the background, such that there is no perspective into the distance and one must focus on the dominance of the central motif of the newspaper, a crucial element in the dynamic of the liberal capitalism of the city. 
colleague Grete Stern, who was beginning to work at the same time in Argentina (Foster, "Dreaming in Feminine; Stern), this means that it would not be quite acute to cite these images as all together spontaneous and unplanned. That is, although there is much that is random in Rosenthal's collection, it is not simply a collection of images of someone who went out on the street and shot only whatever struck her fancy: in addition, as any artist might, to selecting iconic images of the Paulistano workaday world, she also planned images to enrich, one might say, the human presence in them. This is especially intriguing from the point of view of a photography that focuses on the built human environment, the urban cityscape, rather than on the circumstantial human inhabitants of it, as in the case of the photography on São Paulo by the Belgian anthropologist Claude Lévi-Strauss; it is important to note that Lévi-Strauss's images, published under the heading of Saudades de São Paulo, belong to the same period in which Rosenthal worked. Of course, Lévi-Strauss did photograph human beings (but there is a particularly nice image of his father, who pioneered the use of photography in painting), and Rosenthal did photograph some urban spaces in which human beings are absent. Yet there is an essential contrast between these two foreign photographers working in São Paulo in the 1930s: LéviStrauss preferred to study the built human environment, while Rosenthal concentrated on the human presence that occupied it.

Not surprisingly, given the synecdochal nature for Rosenthal's photography of the image of the camarão, she seemed particularly taken by unpretentious urban laborers, young and old, men and women. The latter inclusion is an important one because, while one cannot merely assume that Rosenthal was a feminist, her gaze as a woman (in addition to her gaze as a foreigner) is important, insofar as it cannot have necessarily reduplicated the masculinist gaze of the female body: feminism is not inevitable for a female cultural producer, but masculinism is not either, and the text at the least offers the possibility of encountering a negotiation of the concepts of gender.

For example, there are two connected images of a woman burdened by her load. She wears the dress that, in Rosenthal's own European vocabulary, would likely identify her as a peasant, although she appears 
to be a small truck farmer: rough cut blouses over a long skirt, with cloth stockings and heavy shoes, touched off with the sort of long protective apron down the front typical of country folk. In the first image, she is carrying a large, obviously tightly packed, burlap bag on her head, and she clutches a large squash in the crook of her left arm. In the second image, although she still bears the burlap bag on her head, the squash is on the ground, resting against two other equally full bags and a small market basket containing what appear to be potatoes or other similar vegetables. In the first image, she is standing beside a trolley (a more modest one than the camarão: perhaps one the runs out to the outskirts or, at least, less prosperous neighborhoods, than the route of the latter). It is not clear if she has come into town to market her produce, although she stands alongside another humbly dressed man who is either getting on or getting off the trolley. The trolley announces its run as São Caetano, which is a suburb to the southeast of downtown São Paulo. It would have been very much an outlying area in the 1930s: indeed, São Caetano is the patron saint of laborers, unmistakably an indication of its population base.

The background of both images appears to the central market, which is located north of the downtown, and is today considered a historical landmark. The fact that it is quite small indicates the limited population base of São Paulo at the time. One can compare it to the vast Buenos Aires Abasto; built in the early 1900s and located in the heart of the old immigrant quarter to the west of downtown, the Abasto a Les Halles-like structure befitting the enormous growth of the city in the late nineteenth century (Berjman-Fiszelew). Thus, Rosenthal's image is that of a woman who has come to sell her produce at market, a fact that is confirmed in the second image by a depth shot in which we see the life around the market: other sellers, some customers, produce, a couple of horse-drawn carts that would have been used to transport the produce itself, and the city in the background, extending beyond the facade of the market. Receding in the background is what would have been the trolley that appears in the first image: if the woman has not been let off the trolley with her produce, she has crossed paths with it, in a conjunction of the modern, male-chauffeured device of transportation, and the traditional, premodern female produce 
vendor. Significantly, one can make out in the farthest reaches of the photograph the modern downtown commercial and financial buildings, and the cars parked along the street (contrasting with the horse-drawn carts) and other buildings lining the street attest to urban modernity. Indeed, as ancient as truck farming is, the urban market place is an imposing finde-siècle edifice, well in keeping with the other icons of modernity in the city. Such a building--part of the masculine modernity of the city--constitutes a way of disciplining, that is, organizing and regulating, the farmbased economy that has traditionally come into the city in the form of the chaotic open-air market, which has always, significantly, been dominated by women.

There is, then, a measure of feminism that attaches to these two photographs, both in terms of a woman photographer studied a female produce vendor and form the point of view of capturing the juxtaposition between this traditional form of woman's work and the modern male-driven metropolis. But there are a couple of interesting ancillary details as well. For example, the camera never shows the woman's face, only her left profile in the first image and her back in the second. Indeed, we see her head bent over in the first image from the weight of the burlap bag she carries on her head, as though fulfilling her role as a beast of burden impedes her showing her face. This does not necessarily signify the humiliation of women: Graciela Iturbide's photographs of the working women of Juchitán, Mexico, amply demonstrate peasant women in full, joyfully fulfilled by their work in their world.$^{14}$ In contrast with the anonymity of the faceless producer seller-who then becomes something of a figure of all produce women by her underindividuation, ${ }^{15}$ we have a female onlooker who stares at the camera

14 There is a another photograph, a couple of images later in the collection, that shows five women, all dressed very much in the same peasant fashion, captured face on by the camera; four a very much interested in the photographers interest in them. Behind these women, figures in the daily work force of peasant women, stands the market, with a line of modern vehicles and, most eloquently, the file of telephone and light poles that are essential to the functioning of the modern city.

15 That is, anonymous subjects in a photograph such as this are underindividuated in a prima facie manner; the hiding of the face, typically considered to be the most revealing feature of the human body, only increases and reaffirms that underindividuation. 
as it does its work in recording this scene. That is, there is a triangulation between three women: the produce seller, the photographer, and the female onlooker. Moreover, hits woman is dressed in a more modern fashion that the produce vendor. Although this is not definitively elegant dress--and, therefore, the woman could be a housewife or the housekeeper or a wealthy residence--this woman, assumedly a market customer, mediates between the photographer and the farm woman, since she is part of the economy represented by the public market: if shed weren't there to purchase the first woman's produce, the latter would not be there to sell it, and there would be no basic economy worker for the photographer to study in her two images. Note that we are speaking of two images: it is not frequent in this series for one subject to be devoted two images, and the fact that the produce seller is only underscores her interest for Rosenthal's photographic study.

One final detail: a man in the second photograph, conventionally dressed in business garb, looks away from the camera, as though singularly disinterested in this photographic interchange between women. Yet, a fourth woman, who appears also to be a market vendor, does contemplate the photographic transaction. This fourth woman has seated beside her another person, who also witnesses the scene: it appears to be a male child, probably her own, since young children typically work alongside their mothers in the marketplace. ${ }^{16}$

Other images reveal, however, the dominance of public space by men--men of all ages, as in the case of the ragamuffin with his shoe-shine box, the nicely turned out newspaper boy: long socks, short pants, clean white shirt, 1930s style work cap, and smiling face, offering a newspaper with the headline regarding German troops massed on the Swiss border; this would date the photograph from the end of the 1930s. In another

${ }^{16}$ Another image in the collection demonstrates that open-air markets still existed in São Paulo at the time of Rosenthal's work; the image in question follows the two that I have just analyzed, and it clearly shows the role of male children in the work of the marketplace. In this case, a well-dressed man in shirtsleeves, hat, and tie (other indicators in the photography reveal that it is summertime, such as the parasols carried by both vendors and customers) does contemplate the photographer going about her documentary work... 
photograph, an equally nicely turned out ticket taker on a sleek modern bus tends a client, and one of Rosenthal's best known images is that of a milkman removing a crate of bottles from his equally sleekly modern delivery van. Modernity is here signaled, in addition to the van and its carefully uniformed driver, by the note of modern medicine in the brand name of the milk, Leite Vigor, and the announcement that it is pasteurizado, ${ }^{17}$ but also by the landscaped modern apartment buildings in the background and the overhead telephone/power lines: this is very much the image of a modern "vigorous" São Paulo in its daily routine.

However, from the point of view of a feminist perspective on the city, in addition to the potpourri of images of the male-dominated streets, is one photograph in particular, which attests to the amassed concentration of male presence. Nine men and a pre-adolescent male child are captured in this photograph (in addition, we see part of the shoulder of an eleventh male subject). They are gathered outside of a commercial establishment, perhaps a clothes store, that advertises wholesale and retail transactions (it is common in Brazil to find both in the same commercial establishment), the legend down one of the support columns of the facade announces the availability of tintas (dyes/paints). All of the men are dressed in conventional business attire: suits, white shirts, ties, and hats; at least one is also wearing a vest, and the boy is also formally dressed in a white shirt and pants. At least half of the men are watching something transpiring on the sidewalk to their left: which might be a headline in a newspaper being hawked by a vendor, a street-side pitchman, an altercation--in sum, any of a number of options that would constitute part of the paradigm of what might be called the street theater of daily life in the modern metropolis.

Of special interest in this photograph, in addition to the display of formality in these men dressed for the street--the particular formality of São Paulo is often commented on by comparison to the more informal

${ }^{17}$ Kossoy provides a lovely registry of all of the commercial images and slogans captured by Rosenthal's camera in her gaze of what was by then already becoming the financial center of Latin America. In the section of his essay titled "A São Paulo de Hildegard Rosenthal," he speaks of how "seu olhar se volta para os elementos-símbolo da metrópole” (26). 
Rio de Janeiro ${ }^{18}$--the men here constitute a range of ages, such that there is a generational continuity in the combined masculine presence they effect. For example, to the far right is the young boy. He is at the back of a man in his late 50 s or $60 \mathrm{~s}$, while alongside the latter is a young man in his $20 \mathrm{~s}$, and next to him is a man in his late 30 s or 40 s. While these are very rough approximations, one is struck by how the four male figures clearly discerned in the foreground represents four different age groups: this undoubtedly spontaneous assemblage attests, nevertheless, to how men of all ages dominate the street, and the boy included in the photograph is surely learning to become a man by hanging around with older men. ${ }^{19}$ Moreover, this scene takes place on the sidewalk, which, while they stand outside of one establishment, serves to connect an array of commercial enterprises, the lifeblood of modern São Paulo (one will recall that the historical development of São Paulo goes from being a distribution hub of the agricultural estates of the area to becoming a world-class financial center; all cities are about business, but the business of São Paulo is unquestionably Business ${ }^{20}$.

The sidewalk is, additionally, a very broad space; reasonably even one of the pedestrian malls that emerge as part of the commercial center between the Praça da Republica northward to the Viaduto do Chá. These pedestrian malls, beyond any contribution to pedestrian protection

${ }^{18}$ Varig, the Brazilian national airlines, had an ad about thirty years ago that contrasted the "two Brazils": one, the Brazil of São Paulo, represented by a very European looking man decked out in formal business attire consuming a cafezinho, the French café demitasse; while in the second was purportedly a lied-back denizen of Rio, with his open denim shirt, his wide mulatto smile, drinking from a large cup, perhaps a hearty glass of beer. Such a racially--and socially--charged conception of the two Brazils is not likely to be found in contemporary advertising.

19 A famous Argentine tango by Homero Manzi and Anibal Troilo, "Cafetin de Buenos Aires," has a narrator recount nostalgically how he became a man hanging around this typical male establishment, first by peering in the window from the street and then participating directly in its male-dominated world on the inside.

${ }^{20}$ See the photograph in the collection of the magnificent art deco facade of the Banco de São Paulo, an image that is rotated--in comparison with the majority of the others-- 900 in order to capture the soaring sweep of that facade. The foreground is populated by men, presumably going and coming from its inner depths. 
for vehicular traffic and the intensity of circulating foot traffic they allow, make them veritable stages of urban life. Today, they are, indeed, often spaces for performance art and musicians, but have also become additional commercial spaces, where small business operations that cannot afford fixed space line both sides of the mall and often even the center with stalls, tables, mats and cloths displaying wares in the form of a large open-air bazaar, thereby providing the spectator--and the spectator with camera in hand like Rosenthal--with a geometrically greater inventory of subjects and circumstances. Although Rosenthal may have been primarily interested in studying individuals in the urban landscape, easily a dozen of the photographs appearing in Cenas urbanas concern large multitudes, many of them adequately characterized by the cliché "teaming," while a goodly number of other images focus on the built--and a-building--environment of central São Paulo.

One effective use by Rosenthal of her assistant in a semi-staged photo has here eating a piece of watermelon purchased from fruit cart in the street. This is also a photograph that is dominated by men: to the left the fruit vendor, accompanied, around three sides of the cart by four male customers, all dressed in typical business garb. To the right, a group of three equally formally dressed men in conversation, while a fourth man can be seen beyond the back of one of them. He is not participating in the conversation. The latter are standing outside the door of a men's haberdashery, so once again commerce is an important detail in the photo, permitting the juxtaposition of the informal economy of a street vendor vs. the more modern clothes store. The woman is looking somewhat askance, and closer examination shows part of the body of another woman talking to her, although she is mostly hidden--blocked out--by one of the men in the conversational group. Clearly, the women are outnumbered by the masculine presence on the street, as though they were interlopers in this all male universe. What is quite humorous--and, surely, serendipitous, since Rosenthal's images are not elsewhere marked by any irony of detail--is the fact that the woman is standing directly below a street sign, CONTRA-M $\tilde{A O}$, "wrong way," which the playful viewer might want to read as suggesting--as signing--that the woman is out of place in this street scene. 
I have not wished to argue that Rosenthal had a feminist agenda with her photographs. Rather, the amount of space devoted to the first image--her most famous--underscores that her principal fascination lay with the intense movement of the modern capitalist urbanscape that was fast emerging as definitive in São Paulo seventy years ago. Although as photographs they are static, this image of the trolley and the preponderance of images of cars and commercial vehicles stress the movement of the streets, as do the pedestrians. But there is no escaping the fact that the streets belong to the men of this world of commerce and finance, ${ }^{21}$ and the vehicles are their instruments of work as well. One of the images confirms this in showing an elegantly dressed women paying a taxi driver his fare. Just as other images of buses, trollies, and carts all show male chauffeurs, this photograph stresses how women, if they travel by vehicular conveyance, are transported by men. In this way, an inevitable consequence of Rosenthal's examination of the Paulistano streets of the 1930s is that a woman was studying what was still then very much of a public masculinist realm..$^{22}$

\section{REFERENCES}

ABREU, Marcelo de Paiva; BEVILAQUA, Afonso S; 4 mus, Demosthenes M. "Sustitución de importaciones y crecimiento en el Brasil (18901970): Industrialización y estado en la América Latina; la leyenda negra de la posguerra”. México: Fondo de Cultura Económica, 2003. 210-39.

FRANCESCHI, Antonio Fernando de. “Uma São Paulo ainda gentil.” Rosenthal 5-7.

${ }^{21}$ In the camarão photo, there are thirty-three individuals standing on the street around the trolly. Only eight can clearly be identified as women.

${ }^{22}$ De Franceschi describes the São Paulo of Rosenthal's images "ainda gentil," which leads one to consider the way in which a standard of gentility, while it may be associated with women as its guardians, characterizes very much the universe of masculinist privilege. Thus, the taxi driver shows himself to be deferent toward his female passenger, but he very much exercises a control over her access to the streets and the route to be followed through them. 
DEAN, Warren. The Industrialization of São Paulo 1880-1945. Austin: U of Texas P, 1969.

FERNANDES JR., Rubens. "Modernidad y fotografía en Brasil: Brasil: de la antropofagia a Brasília, 1920-1950”. Valencia: IVAM Institut Valencià d'Art Modern, 2000. 207-61.

FONT, Mauricio A. Coffee, Contention, and Change in the Making of Modern Brazil. Cambridge, Mass.: Basil Blackwell, 1990.

FOSTER, David William. Dreaming in Feminine: Grete Stern's Photomontages and the Parody of Psychoanalysis. [S.1]: Ciberletras 10, 2003. (http://www.lehman.cuny.edw/ciberletras/v.10/foster.htm)

Social Realism in the Argentine Narrative. Chapel Hill: U of North Carolina Studies in Romance Languages and Literatures, 1986.

ITURBIDE, Graciela. Juchitán de las mujeres. D.F.: Ediciones Toledo, 1989 .

JACKSON, David K. Afterword. Industrial Park; A Proletarian Novel by Patrícia Galvão. Trans. by Elizabeth and K. David Jackson. Lincoln: U of Nebraska P, 1993. 115-53.

KOSSOY, Boris. “Apontamentos para uma biografia”. Rosenthal 1530 .

LÉVI-STRAUSS, Claude. "Saudades de São Paulo”. MENDES, Ricardo (org.); NEVES, Paulo (trad.). São Paulo: Companhia das Letras, Instituto Moreira Salles, 1996.

. "Saudades do Brasil: A Photographic Memoir". Trans. from the French by Sylvia Modelsi. Seattle: U of Washington P, 1995.

MESKIMMON, Marsha. The Art of Reflection: Women Artists' Selfportraiture in The Twentieth-Century. London: Scarlet P, 1996.

MORSE, Robert. From Community to Metropolis: A Biography of São Paulo. New and enlarged ed. New York, Octagon Books, 1974. 
POCHMAN, Marcio. “Metrópole do trabalho.” São Paulo: Editora Brasiliense, 2001.

ROSENTHAL, Hildegard. “Cenas urbanas.” São Paulo: Instituto Moreira Salles, 1998.

SACCHETTA, Vladimir. "Pequeno retrato de uma pioneira." Rosenthal 33-35.

STERN, Grete. "Sueños: fotomontajes de Grete Stern." Serie completa. Ed. de la obra impresa en la revista Idilio (1948-51). Buenos Aires: Fundación CEPPA, 2003.

TOLEDO, Benedito Lima de. "Um olhar encantado pelos tipos humanos". Rosenthal 8-13.

. “São Paulo: três cidades em um século”. São Paulo: Livraria Duas Cidades, 1981.

पिएर्, Antonio Luciano de A. Exchanging Glances: The Streetcar, Modernity, and the Metropolis in Brazilian Literature. Chasqui; revista de literatura latinoamericana 32.2 (2001): 35-52. 